\title{
Enlightening Global Communication: Liberation Philosophy and the Intercultural Stand of the 'Other'
}

\author{
Binyam Mekonnen ${ }^{1}$
}

\begin{abstract}
Based on historical records the second half of the twentieth century can be marked as a point of departure for a substantial movement on the topic of liberation across the world; liberation which is contained within a contentious critical popular voice of change on the prevailing and broad political structure of the world. In this period, in different corners of the world people were in protest and war to gain their long lived anguish of being free from the colonial culture of subjugation and exclusion. Although some of the revolutionary movements of this era tended to have economic, socio-cultural and other manifestations, the ultimate anomaly of all these questions were rooted in the ontological and practical premises of liberation, i.e. the enlightenment of the 'Other', the negation of an enforced hegemony, and the reformulation of an intercommunicative just and rational global history of humanity. The key concern of human redemption calls for self-realization as both a particular and universal being by means of methodic politicization. In this paper I sketch the main arguments of liberation theology and Enerique Dussel's liberation philosophy which work for the reconstruction of intersubjective and intercultural communications on the basis of dual redemption in one, which is, emancipation of the 'Other' as an initial and the emancipation of humankind as an end.
\end{abstract}

Keywords: 'Other', enlightenment, exteriority, intercultural communication, universality, trans-modern pluriverse

${ }^{1}$ Assistant Professor of Philosophy, Department of Philosophy, Mekelle University 


\section{Introduction}

Humanity as a living entity raises the question of freedom to express a natural inseparability of existential compartment from the will to life. As Hegel's Phenomenology of the Mind exposes humans are driven by freedom. Though human life is manifested in diverse sorts of dynamisms, liberation is permanently presenting itself within a paradigm of the common interest to survive. This is to mean there is no possible way of understanding humanity independent of liberation; this is the quest of survival in its own. In the reductionists' philosophy, particularly in contemporary dominant political thoughts, there is a crucial attempt to comprehend human liberation under the realm of liberalism's doctrine of liberty. But the liberal description of liberty is insufficient in attaining human emancipation for it has only an economic and political assertion. And this makes the liberal ideology of freedom narrow in scope, and barrier to realize genuine human emancipation.

But in its broader sense, the conception of redemption emerged in Immanuel Kant's discourse of the Enlightenment. The metaphor of the Enlightenment is coming out from darkness to light. The first paragraph of Kant's 1784 essay What is Enlightenment? clearly states the summary of the philosophic task of dismantling human backwardness and fear:

Enlightenment is man's emergence from his self-imposed immaturity. Immaturity is the inability to use one's own understanding without the guidance of another. This immaturity is self-imposed when its cause lies not in lack of understanding, but in lack of resolve and courage to use it without guidance from another. Sapere Aude! Have the courage to use your own understanding! is thus the motto of enlightenment.

Here Kant emphasized that human beings are capable for emancipating themselves from the condition of total imprisonment using the power of reason. He conceived reason as the only essential instrument in which rational agents struggle for liberation from the veil of ignorance and domination. In Kant's emancipative analysis of the Enlightenment, one can ponder a self-reflective understanding of humanity which flourishes from status to end immaturity which is indeed a conscious comprehension of the self that concerns every rational being. It is here that his idea of a universal reason shows the necessity of a new emergence of humanity. In short, the Enlightenment is about human redemption in a philosophic sense and it affirms a human being is his or her own liberation.

Enerique Dussel, who is among the famous proponents of Liberation theory, argues that his project starts with an identification of the original link between the 26 
current turmoil of human globalism and the irrational aspects of modernity. In his critical study Dussel says the origin of modernity is not only tied to rational principles of the modern self, and there, values of liberty, equality, fraternity and so on, as described by many Western/European thinkers, but also compounded by irrational destructive myths and ideologies. This implies that the myth and ideology of modernity are irrational, for the reason that aggression, domination, alienation and exclusion are its manifestations: "Modernity dawned in 1492 and with it the myth of a special kind of sacrificial violence which eventually eclipsed whatever was non-European" (Dussel 1995: 12).

In this article I introduce liberation theology and liberation philosophy in their specific orientation of emancipation. I also explore Dussel's philosophy of liberation of liberating the 'Other' and reconstructing the project of modernity within a trans-modern pluriverse which aims at the abandonment of the destructive forces of modernity while actualizing its universal rational positive values. The paper contains three major topics and a conclusion.

\section{Redemptive Theology and Existentiality: How to Read the Holy Bible?}

In Latin America the thought of human redemption began to be associated with religious praxis in the twentieth century to dismount the structural order which makes the majority of people there, to be dominated culturally, economically and politically. Being in the theological prism a majority of Latin American Christians argued for a cultural transformation in the interpretation of the Gospel. By broadening the horizon of the cultural revolution of the question of redemption into economic and political matters, they raised three radical themes under the general idea of their liberation theology. These are " (1) an interpretation of Christian faith out of suffering, struggle, and hope of the poor; (2) a critique of society and ideologies sustaining it; and (3) a critique of the activity of the church and Christians from the angle of the poor" (Levine 1988: 243). Accordingly, redemptive theology privileges the poor in interpreting the Holy Bible from their own ontological existence. The poor have the right to use their religion as a means of transformation and to interrogate on the dehumanizing imprisonment of the socio-cultural order and the resulting poverty, misery and barbarity.

As far as liberation theology is concerned, religion is the best weapon with which the poor socio-historical dehumanization and slavery can be rejected. And the proponents suggest that:

... religion has a primary role to play in human liberation, and that in the search for liberation, transmitting the Gospel's message of salvation cannot be separated from the creation of a better life, "here" and "now" (Ibid: 241). 
The "here" and "now" claims of theology of liberation considers religious emancipation in its actual connection to the earthly life search for the good life. This implies that the religious quest of liberation is important in refuting the inhuman social crises. One of the Peruvian liberationist theologians, Gustavo Gutierrez sees the functional role of theology. For him "theology is flux; it is dynamic and an ongoing exercise involving contemporary insights into knowledge, humanity, and history" (Rohodes 2011: 3). This point seems quite significant for the hermeneutic understanding of Christian religion based upon the horizon of the existential life of the 'Other', i.e. the poor and other dominated subjects. As real children of God, liberationists affirm that, we need to let our religion in its openness which evolves in accordance with the transformation of this worldly life. Here it is very sound to see the full idea of Ron Rhodes on the divergence between traditional Platonic Christians' and liberation theologians' conceptions of God:

\begin{abstract}
Liberationists argue that the traditional Christians' doctrine of God manipulates the divine being such as that He appears to favor the capitalistic social structure. They claim the orthodox view of God is rooted in the ancient Greeks who saw God as a static being distant and remote from human history. This distorted view of a transcendental deity has, they say, yielded a theology that understands God as "Out there," far removed from the affairs of humankind. As a result, many Latin Americans have adopted a passive stance in the face of their oppression and exploitation... Liberation theologians have thus tried to communicate to their compatriots that God is not impassive. Rather, He is dynamically involved in behalf of the poor and downtrodden. And because God stands against oppression and exploitation, those who follow him must do likewise. Indeed, Gutierrez says that "to know God is to do justice" (Ibid).
\end{abstract}

As a matter of fact, the core concern of liberation theology is on the poor who are in imminent danger because of the historical structure of world politics in modernity. So long as a theory of redemption examined the rational and irrational aspects of modernity, the oppressed-poor of the world make their critique towards the global political structure of the world, which includes an economic and cultural domination within the system of capitalism.

In line with Karl Marx's criticism of capitalism, liberation theologians take the critical-practical-revolutionary tasks of philosophy as a way of understanding the existential conditions of a society further into new interpretation of the Christian faith as a call for the total transformation of humanity and the world: 
Christian faith becomes a critical and dynamic leavening in revolution. Faith intensifies the requirement that the class struggle processed with determination towards the emancipation of all humanity-in particular those who suffer the harshest forms of oppression. It stresses our aspiration to a total transformation of society rather than a simple transformation of its economic structures. Thus faith brings to the Christians involved in the struggle, and through them, its own contribution to a society qualitatively different from the present one, and to the appearance of the New Man (Lowy 1988: 244).

Hence, as Marx, liberation theologians accept that it is through criticalpractical-revolutionary thinking that a transformation could only be attained in the world. Of course there are differences between Marx and liberation theologians; Marx's emphasis is on practical philosophy or secular critical revolutionary activity whereas liberation theologians' focus is on Christian praxis. Indeed secular liberationists are more Marxists than the religious ones. Despite this, there is also a strong Marxist tradition among the liberationists on the notion of practical solidarity.

Talking of the Marxists' idea of practical solidarity in particular, Andrew Levine tends to note that social revolutionary emancipation necessities the ending of domination. Marx's practical solidarity sees the social power of the 'wretched of the earth' to destroy class antagonism and social destruction. Levine expresses this as a solidaristic politics and ethics which promote the actual transformation of the status quo providing primacy to the oppositional genuine rationality and action of the marginalized (1993: 73).

If the issue is about total transformation, then there could be no means of achieving this as individual or even isolated group. This argument sounds like a socialist critique of liberalism. It is noteworthy here to deal with the Basic Christian Communities or Base Ecclesiastical Communities' (CEBs) crucial tasks in bringing solidarity and social consciousness about how to struggle for equality and justice. As the central religious claims of Hebrews and Christians on justice and love respectively, liberationist Christians of Latin America make their central focus solidarity. The $C E B s$ in this respect try to unify people under a collective sentiment to read and get the meaning of the Holy Bible from the perspective of the poor or the dominated. The very nature of the $C E B s$ is to protest the traditional fidelity that the church had to reach and elite groups. Because of the $C E B s$, liberationists say we have a new stand today, and their claim is "today the Bible is 
read in small villages or barrio level groups by people sitting on benches, often in the dim light of a kerosene lamp" (Levine 1988: 253).

From this, one can understand how the social consciousness and transformation evoked by the $C E B s$ gives a special attention to the poor and farmers in the country side. This attempt of the CEBs is aimed at fostering solidarity of the poor or the dominated in order to gain his or humanity, equality and justice. In other words, the rationale of solidarity is to abolish all conditions of dehumanization and repression. $C E B s$ also have the task of enabling people to meet their basic needs and enhance their moral support (Ibid: 249). In short the CEBs manifested their social transformative mission by incorporating Marx's notion of communication with their existential and self-conscious study of the Bible.

As an objective here I am using liberation theology as it transcends a theological purpose. Having a humanist Marxism point of view one can see human liberation in its totality where religion is one of the compartments. Liberation theology is crucial in articulating the human ontological and ethical questions so that responses are given in addressing human failures in whatsoever sense. On this account the problems and solutions that liberation theology identified to the human crises are relevant to the existential philosophic quest of liberation. Of course it is clear that there is a difference between theological and philosophic liberation theories though both define human liberation as their essential goal. In the coming sections I will discuss the Dusselian liberation thought which employs a uniquely philosophic method of human liberation.

\section{Where to Start Human Emancipation? Transcending Habermasian Modernity}

All scholars of modernity accept the fact that it is a universal interest to actualize emancipation. And in most of these thinkers' view the possibility of achieving human liberation is given to discourses that have both theoretical and practical projects of communication. Nowadays the rise of intercultural philosophy, most importantly Franz Wimmer' spolylogue theory is taken to be fruitful in establishing communication of discourses. But before that task of intercultural communication it would be very significant to look at the question where to begin the project of emancipation. Most thinkers from the Global South suggest that the proper starting point for emancipation is the ontological sphere of the 'Other'.

The human condition of the 'Other' for the past six hundred years has been analyzed as slavery. Because of an irrational negative myth of Europe, Dussel states that the 'Other' is considered to be unenlightened. Hence, the sacrificial 
myth of modernity views Europe's colonial conquest of the 'Other' as an emancipative strategy:

...the conquest is "for the good of all" and of "great benefit" for the dominated, vanquished one, perfectly expressed the myth of modernity. One defines one's own culture as superior and more developed and the other as inferior, crude, barbaric, and culpably immature...Even the violence inflicted on the Other is said to serve the emancipation, utility, and wellbeing of the barbarian who is civilized, developed, or modernized. Thus after the innocent Other's victimization, the myth of modernity declares the culpable case of that victimization and absolves the modern subject of any guilt for the victimizing act (1995: 64).

The sacrificial myth of modernity is accountable for the loss of human in the colonized world including Africa, India and Asia. This is the myth which caused the death and sufferings of minority groups in Europe: "the victims of modernity in the periphery (the extermination of the Indians, the enslavement of the Africans, the colonization of the Asians) and in the center (the genocide of Jews, the holocaust) are the "responsible" ones for their own victimization." (1996: 52)

This explicitly shows that the irrational myth of modernity is given to undermine the majority of humanity of the world in the name of barbarity. The principle of a just conquest began to be used for the mechanism of an aggressive abandonment of the savageness of the Amerindian, African, Asian and the Jews. This irrational myth of modernity will be applied from the conquest of America (genocide of the Amerindian), to the enslavement of the African, to the Chinese Opium War, to the invasion of Panama (1990) or the Gulf War (1991)" (Ibid). Employing this word "just" war is waged on the so-called barbarous people. The irrational myth of modernity constructs a system of alienation of non-European subjects.

Since this myth discriminates against non-whites in favor of the white people we can argue that it is an exploitation of one's identity on the ground of color. Liberation of the 'Other' is therefore, seeking to differentiate the rational and progressive aspect of modernity from that of irrational sacrificial myth contained in its entire project. Western domination through colonialism is still perpetuated in another form within the system of globalization, capitalism, liberalism and 'world democratization'. To end this system of domination, not the mere idea of freedom echoed politically from the second half of $18^{\text {th }}$ century, but the praxis of redemption is important. Since colonialism continues in the Western principles of 
homogenization, democratization, development and so on, we need to be very critical of emancipation practices that could be employed in the world.

Jurgen Habermas, who is among the influential figures of critical theory, endorses the task of liberation in our age with reformulating Marxian philosophy in the light of contemporary social changes. Habermas' theory of communication tries to develop a postmetaphysical and postconventional idea in which language becomes its central concern to insist that the intersubjective communication of people makes rationality and action possible. There are at least two profound grounds of communicative theory that show its divergence from the old metaphysical and conventional paradigm of consciousness and which mark a new beginning.

The first difference appears in its focal concern to language as a significant aspect of human development. To signify this, the noble trend that Habermas comes up with is called a postconventional self who puts every question into a democratic discussion. Of course one may think, this postconventional identity has an intimacy with the modern self of the enlightenment who fought with doubt, ignorance and laziness in Descartes and Kant. However Habermas' postconventional self evolves not in the philosophy of the subject, rather in an intersubjectively emerged community. In the Postmetaphysical Thinking, he says

The self is intersubjectively constituted through and through; the relation to a community is what makes the practical relation-toself-possible. If the individual is to realize her true identity, she cannot do so by withdrawing from this community (1992: XVII).

The postmetaphysical self of Habermas' theory of communication asserts that the metaphysical argumentations of a self-certain, self-known, transcendental and authentic self of the previous philosophical thoughts are all questionable methodologically in so far they denied the intersubjective nature of the meaning and validity of truth. Accordingly, the new self in Habermas' theory explains that meaning and validity is a social production, given that language is the only means to reach the truth. But this does not mean the meaning of validity claims is absolutely relative. This point will lead us into the second special marker of Habermas' theory in comparison to metaphysical philosophies.

The second ground of theory of communication is the universality of validity claims. Once a linguistic meaning is granted then its validity is universal due to the criteria of being true, right and sincere. Whenever and wherever a given speaker defends a claim the universal validity claims are evoking conscious reflections and consent of the hearer. It is through this intersubjective communicative action that 
the speaker and the hearer can develop a rational agreement. This is the fundamental to a linguistic communicative action.

[W]ith her utterance a speaker makes a truth claim relating to the objective world of states of affairs, a rightness claim relating to the social world of normatively regulated interpersonal relations, and a truthfulness or sincerity claim relating to the subjective world of experiences (Ibid: IX).

By this, Habermas' communicative theory attempts to place the speaker and hearer in a position which could be thought as symmetrical. In other words, his theory of communication can take place among people who present themselves in intersubjectively constituted postconventional societies. In his Communicative Action, he tries to describe the current global system and its life-worlds in the context of a postconventional understanding of the modern self and of the world. He insists that the emancipative interest of global humanity can only be attained today by using the theory of communication which fosters the discourse of consensus.

Nevertheless, using Dussel's liberation theory one may ask questions such as: to what extent can the theory of communication be solid to address the existential human crises given the pervasiveness of political and economic authoritarianism? How can we think the myth of symmetry in the current world in relation to the economic, political and cultural manipulations considering North-South communication? What is our philosophic reason and defense to the daily reports of hunger, war and death of millions of people of the Planet which are directly associated with the irrational games in societies and governments? Is there actual draft in Habermas' project to restructure the so-called universal organization as humankind who works for realistic emancipation? For Habermas the discursive talk among participants will lead into mutual enrichment of communication. Accordingly, his communicative theory is on the dialogical universal human communication which is governed by universal validity claims and postmetaphysical participatory logical interactions (Habermas 1987: 126). But according to Dussel Habermas' communicative discourse lacks the ethical content of human materiality. By human materiality is meant the total realization and maintenance of human life. That is why Dussel sees the ethics of the material as the end affirmation of all of humanity. He states that, "One who acts humanely always and necessarily has as the content of their act some mediation of the responsible production, reproduction and development of life of each human subject, in a community of life, as material fulfillment of the needs of their cultural corporeality." (Dussel 1998: 132) 
In the theory of communication, as Dussel (2008: 16) says, interphilosophical communication of individuals and philosophic traditions in the world is important. But Habermas' theory fails to take a serious account on the racial and class differences in the world. As far as Dussel (1996) is concerned, the modern capitalist system made some superior over the others. To justify this he illustrates the "racism of Apartheid in South Africa", and wealthy individuals and nations developed at the expense of the poor (Dussel 1996: 30-31). With these essential differences we can see inequality among humanity and nations of the world. Thus, redemptive philosophy provides a critical position in relation to the existential political, social and economic inequalities of the world. And because of this very reason it seeks to transcend Habermas' theory of communication.

Dussel disagrees with Habermas' distinction of lifeworld and system especially from the juncture of "North-South" political and economic relationships and communications. In this understanding, the life world of the "North" i.e. a European-North American lifeworld is functioning as a system of domination and exclusion for the "South". In other words, the lifeworld of the "North" is "the hegemonic, dominating one that, with respect to the [other], exercises a function very similar to that of the colonizing system of oppression (Ibid: 30 ).

All of this clearly implies that, in Dussel's liberation critical theory the primary task is the banishment of the political arrangement and system of oppression. But the end objective is like Habermas' theory of communication insuring the emancipation of the world of humanity which could only be attained through an intersubjective recognition and communicative consensus. It is within this core theme and way that we can make trans-Habermasian liberation. Dussel transcends Habermas' universal communication of rationality giving a privilege to the political and ethical development of the oppressed. Thus, the oppressed set a sort of ideological fight to overcome dehumanization and maintain actual human emancipation.

\section{Rationality and Polylogical Communication: What is the Stand of the "Other"?}

Throughout the development of philosophical discourses the subject matter of reason is grounded on the nucleus, as the first and last of all fundamental labors of philosophy in which other topics follow either to affirm or deny for its roots. The Gospel of John understood reason [logos] as a cosmic order in which everything else is structurally created. It is from that reason that the metaphysical concern of cosmological and ontological orders is developed. Parallel to this metaphysical assertion of reason, many thinkers have dealt with the nature, scope and limit of earthly knowledge within a prism of Aristotle's famous quote which says "Man is 
zoo logos". This is to mean, that human curiosity to know about the world and themselves arises from the fact that their mind has been cultivated with the character of rationalization.

The merging of interest in philosophical and scientific thoughts notoriously raised the point that humans differ from brutes through the power of reason that aimed at the "disenchantment of the world" (Horkhiemer and Adorno 1982: 3). Hence, the modern project of philosophy i.e. Enlightenment's program of the disenchantment of the world, pondered the necessity of human redemption from the general condition of irrationality. The disenchantment of the world, insisted up on by the Enlightenment thinkers, shows that human beings have the power and courage of rationality, which is either essential peculiarity in the animal kingdom based on species-genus difference.

However, a deep critical investigation of the project of modernity necessarily raises the question of how our hermeneutics of man as a rational animal transcends the logical level of species-genus difference, and looks more intensively at what conceptions of Man ontologically and epistemologically imply concerning the historical situations of humanity in the world. Based on historical grounds, Magobe B. Ramose points out that Aristotle's view of Man as a rational animal tended to marginalize and exclude certain groups of humanity such as women, Africans, Amerindians and Australasian from the crown of rational-conscious being (Ramose 2002: 1). Therefore, these discriminated and negated groups of humanity could never be seen as proper Humans in their ontology, and consequently, it is reasonable to say that Aristotle's claim from the historical context recognized the above listed peoples as the 'Other' who are illogical and prelogical.

No one denies the Enlightenment promises to promote the use of reason for the betterment of the world. In this respect, discourses of rationality are contained within an ethical project to excel the power of reason in reconstructing the human world, enhancing its goodness and creating better form of life with humans, the master of the earth. In the eyes of the Enlightenment proponents and their followers, reason is about process, success, and emancipation. On the contrary, the critique of the Enlightenment is given by showing the historical records in which modernity and its Enlightenment program are not rational as thought to be so long as they contain violence and myths of various sorts. The main point of this critique is that the "authoritative rationality" of modernity seems to lead destruction, violence, and the hegemony of a mythic power. For instance, in the Dialectic of Enlightenment, Horkheimer and Adorno explain the Enlightenment project in their words as based in the power of totalitarian myth and human dictatorship over nature based upon the scientific motives of utility and alienation (Horkheimer and Adorno 1982:6-9) (emphasis mine). This signifies the disenchantment of the world 
is prescribed in relation to a scienticism of its myth, under the consumerism treatment of nature and the application of one-dimensional instrumental rationality instead of the rational emancipative construction of human sovereignty. If this is the case, then the imposed authorities and the myth are no longer crashed, rather preserved and transported into the totalized project of the Enlightenment.

\section{The Need for Exterior Critique of Modernity}

Dussel underscores that modernity contains both progressive and regressive elements in its program of the Enlightenment. Specifically in its destructive content, he (1993) says, the challenge is not only the physical conquering of Europe on the other parts of the world from $15^{\text {th }}$ century onwards, but also the hegemonic suppression of cultures and cultural identities which actually contain their own diverse rationalities. On this account, Europe invented itself as the center of the world in domination and Eurocentered inclusion of the peripheral traditions. And one of the problems of the centrality of Europe in modernity is the judgment of human maturity and civilization in relation to European mentality only. This is an attempt to universalize the culture of rationality of Europe through European expansionism. Within the context of this expansionism, philosophical and anthropological discourses of the Enlightenment and also Christian theological writings justified the subordination of the 'barbarians-prelogical' by the 'civilizedlogical' European's power and knowledge.

When we look at historical records, it is the very fact that in most great civilizations of the world including the pre-modern ones, the people and society who promote their great achievement often take the position of the center while directing others to be their admirers and possible followers. The core objective of constituting the center is to expand the culture of civilization to the other parts so that the development utility of a civilized culture transcends its particularity in terms of the inclusion of the 'Other' in an ethnocentered outlook. But for Dussel there is a big gap between pre-modern cultural civilizations of the world and modern European culture in both of means and end for controlling the center of the global system. He states:

All the great Neolithic cultures were "centers" of civilizing subsystems with their own periphery, but without any historical significant connection with other ecumenes. Only modern European culture, from 1492 onwards, was a center of a world system, a universal history that confronts (with diverse types of consumption and exteriority) as all other cultures of the earth cultures that will be militarily dominated as its periphery (Dussel 1996: 132). 
In this respect, modern European culture made world-wide expansion not only to show its civilization but also to dominate other cultures of the world employing its military achievement. Hassen Hanafi distinguishes two cultures which are developed due to the European global expansion; one is, "Culture" with a capital "C" which represents the European culture that aspires for central position and power of supremacy, and the other is, culture in small "c" that refers to the alienated cultures of the world (Hanafi 2001: 43).

Modern European cultural expansionism according to Dussel has developed itself in confusing its particularity, which is pure Eurocentrism, with universality. That culture displaces other civilizations, philosophic traditions, and identity of the non-Europeans by claiming that Eurocentrism is the only and universal culture of humanity. However, the success of modern European culture for Dussel can only be gained in its historical relation with non-European cultures. And this relation is a perpetual dialectic of cause-effect:

Modern European culture, civilization, philosophy, and subjectivity came to be taken as such abstractly human-universal. A great part of achievement of modernity were not exclusively European but gorse from a continuous dialectic of impact and counter-impact, effect and counter-effect, between modern Europe and its periphery even in that which could call the constitution of modern subjectivity (Dussel 1996: 132-33).

The philosophical and anthropological discourses of modernity are largely construed based on the dialectical relation of European hegemonic invasion, and therefore, non-European cultures are made to be victims of violation and degradation. For this, it is sound to put an exterior and subaltern examination on Kant and Hegel's project of modernity in line with their discriminatory anthropological orientations. Dussel presents his conception of exteriority as a new possibility in redefining modernity from the underside perspective. This perspective seeks to criticize the irrational sacrifice myth of modernity: "As rational critique from the Exteriority of modernity, the "other face" of modernity, trans-modernity (Amerindians, Africans, Asians, etc.) criticizes the irrational myth of violence against the colonies, peripheral capitalism, against the South." (Ibid: 53)

Emmanuel C. Eze tells us that Kant is known by his main motive of making reason as a human asset universally particularly in his three philosophic works of Critiques and short article of the Enlightenment. However, Eze says such universality interest of Kant's philosophical thoughts disclosed as a road map for 
crystallizing and justifying the rationality of European expansion and colonization of the non-European topographies and demography. As evidence, Eze provides the anthropology and geography lectures of Kant in which a racial categorization is maintained. In the context of his reflections on the "Color of Reason," Eze elucidates the racial thoughts of Kant based in several lectures on the "twin sciences" (anthropology and geography) in which he explains the natural relation of Man's inner and moral aspect with the physical color of the body. These twin sciences of Kant intended to justify the diverse race of Man in the world in terms of hierarchical divisions and differences of the inner quality, which are the rational and moral variations among races of white, yellow, black and red (Eze 1997: 105). By representing the white or European Man at the top of the tangible and 'Form' of racial ladder, Eze explains that, Kant established the supremacy and universality of the one race over other/the 'Other'. Here is Eze's argument:

Kant's theoretical anthropological edifice, then, in addition to its various conscious and unconscious ideological functions and utilities, had uncritically assumed that the particularity of European existence is the empirical as well as ideal model of humanity, of universal humanity, so that others are more or less human or civilized "educable" or "educated") as the approximate this European ideal (Ibid: 117).

With this anthropological deviations of the 'Other', Kant affirmed that the Enlightenment project of releasing human beings from self-imposed immaturity is given for the 'enlightened,' 'liberated' and 'civilized' European Man. This can be viewed as a struggle to transcend Eurocentrism into Universalism. The logic is simple in that Kant's anthropological explanations justify the civilizing mission of the European self to liberate other people from the status of tutelage. Accordingly, humans can only accomplish their redemption once they are incorporated into the European ideal of universal humanity. The white (European) Man is the model of humanity in so far he is a rational and moral species.

Many scholars believe that Kant's Eurocentrism originated from missionary and anthropological sources which observed that people in the dominated areas are in the state of backwardness both physically and mentally. The argument of these scholars is that Kant never had any contact with non-European people. Nevertheless, Tsenay Serequeberhan thinks that the Eurocetrism of Kant ought to be clearly understood as an attempt to establish the universality of European identity and history through the logic of surpassing necessity. As Serequeberhan writes: 
Kant's explicit endorsement of European expansion and conquest (as the beneficial effect of the providential and secret design of nature) is not due to his lack of sympathy for non-European peoples; nor is it an accidental or extrinsic aspect of his historical thinking-an easily excusable "blemish". It is rather ... the effect of his universalistic and universalizing discourse grounded on the Ideal that European history is the "transcendentally obligatory" meeting point of all particular histories (Serequeberhan 1997: 153).

Analogous to Kant, Hegel emphasized the necessity of reason in his lecture of Philosophy of World History. The parallelism of him and Kant is evident insofar as Europe constituted the center of the world in modernity, too. According to Hegel the history of the world moves from east to west. The fundamental argument of his Philosophy of World History book affirms that the center and absolute end of human civilization will be the heart of Europe and Asia is the starting juncture. This assertion of Hegel displaces Africa and Latin America from the history of the world.

In relation to Africa Hegel develops a claim that the continent which has a physical feature of "enclosedness" and is culturally primitive. He classified the continent into three sections on the basis of spiritual and cultural merit. The first part is "North Africa"-Maghreb Africa. And he characterized this region by its significant attachment with the Spaniards, the Phoenicians, the Romans, the Vandals, the Arabs, and the Turks. This is to signify that North Africa is spiritually non-Africa since a considerable influence is made by peoples of Europe and Asia. The second part, "Egypt"-Nile Valley is rich and a symbol of great civilization which might be looked from the perspective of its territorial and spiritual relation to Mediterranean Europe. Again like North Africa, the Nile Valley for Hegel represents a non-African spirit that should belong to the Mediterranean civilization. He regards the third region, "Africa proper"-Sub-Saharan Africa as real Africa whose spirit is barbarism and savagery (Ibid: 172-73). For Hegel, Africa proper describes the true essence of Africa, that is enclosed within itself, departed from the centers of human civilization, and the world. This is a spiritless territory in a sense that no European sorts of civilization; politically, socially, economically and religiously were established before Europe expanded and conquered the region.

Saying all this, Hegel goes to justify the righteousness of slavery that Europe should follow in her relation to Africa: 
Since human beings are valued so cheaply, it is easily explained why slavery is the basic legal relationship in Africa. The only significant relationship between the negroes and the Europeans has been-and still is - that of slavery. The negroes see nothing improper about it, and the English, although they have done most to abolish slavery and the slave trade, are treated as enemies by the negroes themselves... The negroes are enslaved by the Europeans and sold to America. Nevertheless, their lot in their own country, where slavery is equally absolute, is almost worse than this, for the basic principle of all slavery is that man is not yet conscious of his freedom, and sinks to the level of a mere object or worthless article. In all the African kingdoms known to the Europeans, this slavery is endemic and accepted as natural (Ibid: 183).

The language of emancipation in the Negroes can never be raised if they take slavery as innate to their very natural existence. This seems the Negro is never ready to make a dialectical move and negate the natural will, and remains in a state of natural enslavement and subordination to rational creatures like the Europeans. Hegel is saying that, the Negroes live their life not as an intrinsically valuable, rather as an object that always serves as an instrument. So for Hegel it is rational to colonize Africans and exploit their extrinsic value.

In terms of morality, Hegel says, the Oriental World - Asia has shown the supreme of humanity radically different from the Negro world. In Asia he admits that there is power of rationalization that works on the ethical supremacy of Man's life which is the rock stone of a political consciousness:

We find here a power which exists in and for itself, and man only exists in and for himself in so far he is related to this universal substance. It is this relationship to the substantial power which unities the individuals with one another. Thus, it is Asia that the ethical world of political consciousness first arose (Ibid: 190).

From this one may argue that, Hegel develops an optimistic outlook towards the Asians. But still we can see his pessimism when he views Europe as the center and perfect end of world history. Following his logic, contemporary economic and political philosophy scholars of the Global North attempt to explain the basic link of the Christian colonizing project and the system of capitalism, which is why they most often say, capitalism is the end of history. For Hegel and his followers, Europe represents the perfect consciousness and takes humanity to the peak of world civilization. But in the move towards the end of history the reason of Europe 40 
has to be the hegemonic model of spirit of thinking by its virtue of not only intrinsic moral and political human rationality, but also to the technological and scientific progress of the world. On this level of analysis it looks like logical for us to take Hegel's idea which says, "what is rational is real; what is real is rational" as a ground for exploitative European rationalism and capitalism.

In his article "Eurocentrism and Modernity" Dussel attempts to examine the philosophical biases of Kant and Hegel in relation to the human development projection, and he insists both the Kantian program of the Enlightenment and the Hegelian project of World History contain strong ethnocentric justification about how Europe and its culture are superior to others (1993: 68-73). Therefore it is quite essential to apply an exterior critique so that we can identify the underside of modernity. Such application of exterior criticism is advantageous not only in its crystallization of the rational and irrational contents of modernity which is largely structured by European hegemonic rule, but also calling for diverse traditions of the world to engage in mutual intercultural communication as they can achieve the global interest of human redemption.

\section{The Voice of the 'Other' for Global Communication}

The communicative theory of Habermas has the goal of reconstructing modernity by showing that the unfinished business of the Enlightenment can only be realized through the power of rational consciousness. Postmodernism was highly criticized by Habermas for "disempowering ideas of reason altogether" thus discrediting the emancipative focal of modernity. He underlines on the need of increasing the rational and emancipative ideals of the Enlightenment (Hoy and McCarthy 1994: $31)$.

In Knowledge and Human Interests, Habermas argues that emancipation arises from self-understanding and self-reflection (Clarke 2006: 61). This is analogous with the motto of the Enlightenment which insists that humans are free in so far they acquire the knowledge of themselves from the Kantian principle of the Enlightenment; Habermas underscores the social and historical context of reason, which is rational innovation in interpersonal communication. The cognitive interest of human knowledge for Habermas appears in three distinct but interrelated interests, namely; technical, practical, and emancipatory. As Steven Best will show, Habermas' articulation of the three forms of human cognitive interests has its own specific objectives:

A technical interest in controlling objective process, a communicative interest in forming an intersubjective world through linguistic symbols, and an emancipatory interest in becoming self-reflective, self-determent (Best 1995: 152). 
The cognitive seek of hard sciences or an "empirical-analytic" thought is a technical one for its concern to produce objects and governing nature. The cognitive seek of historical-hermeneutic sciences is the result of interpretive activities of intersubjectively communicating individuals to reach consensus within a frame of "linguistic tradition". And the emancipative seek of critical theory is to achieve human liberation (Ibid: 152). In all knowledge, Habermas says, there is human interest. In this respect, the empirical-analytic sciences are interested in making of materials for survival's sake, the practical sciences are concerned to develop value analysis, judgments and interpretations of social embodiments, and critical discourses are devoted to achieve the emancipative interest.

Although these three interests are interlinked with one another, Habermas is chiefly concerned with emancipatory cognitive interest in the theory of communication. Hence his theory of communication is one of the critical sciences that stresses on liberating humanity from domination and exploitation. The communicative theory of Habermas states that human emancipation takes place if and only if there is a rational consensus of participants based in universal validity claims among the participants of a shared linguistic tradition. These validity claims are formed in the speech act of an utterance to give meaning of something in the manner of pragmatic relations that a speaker has with either the objective world, or social world, or subjective world (Habermas 1987: 120). The pragmatic relations of the speech act of an utterance of the speaker in the three worlds explain the universal validity claims of truth, rightness, and sincerity (Ibid 1992: ix). This is the main reason for Habermas to develop his communicative rationality and action based on a postmetaphysical tradition in which language is central.

A postmetaphysical approach is used by Habermas to show the hard core of a social mutual interaction in enlightening critical understanding and argumentative consensus. In the theory of Communicative Action Habermas puts;

Coming to an understanding [Verstandigung] means that participants in communication reach an agreement [Einigung] concerning the validity of an utterance; agreement [Einverstandnis] is the intersubjective recognition of the validity claim the speaker raise for it (Ibid 1987: 120).

Habermas' theory of communicative rationality and action supplies important insights to us in order to widen and get the exact value of reason in developing critical sciences of contemporary world. It does it by considering the question of emancipating human beings from domination in relation to the other two cognitive seeks. Moreover, his understanding of reason as the only tool to bring about 
communication in a shared linguistic tradition reflects the necessity of intersubjective dialogue among participants. From the perspective of the philosophy of liberation, there is no doubt that, Habermas' arguments about the positive essence of reason display a crucial role on the present and future of critical theories.

But there are suspicions as to how far that the communicative theory and other thoughts of Habermas have been distanced from the Eurocentric reason and its rationality tradition. For instance, his view of a postconventional society could be seen as a mirror of Western liberal community, in which participants ideally, have an equal voice to engage in discussion and mutual understanding. Here the concern would be what is and will be the communicative process among the richindustrialized and the poor-developing world people, men and women, the big Culture of the West and cultures of the periphery zone. From this we may conclude that Habermas' view of the universality of communication is entirely Eurocentric.

Dussel points out that in any linguistic expression there is meaning and rationality at least until a refutation is made. And in different cultures there are a number of rationalities in which we are employing a rational system of reflection on the foundational mythic traditions of the world. Humans cannot escape from myths to give a rational understanding of the world; "the production of myths was the first rational forms of interpretation or explanation of reality (of the world, subjectively, the ethical practical horizon, and the ultimate reference of reality that is described symbolically)" (Dussel 2008: 2). Therefore, in different horizons we have varieties of reason. But these diversity of reason will become one when "symbolic rationality" of myths develop into the "rationality of philosophical conceptual categorization" (Ibid: 4). Philosophic rationality works on the condition of shaping conceptual frameworks through communicative engagements. But one thing is clear here, that is some reasons originate from myths which are rational to the extent of their linguistic structure and expansion. Dussel's liberation critical theory strongly opposes any sort of ethnocentrism of reason, and asserts the need for transcending particular and symbolic rationality into the rationality of philosophical conceptual categorization, particularly in the course of communicative practice.

Recognizing this claim of Dusselian critical theory, one can talk about the diverse nature of reason and rationality traditions of the world, and their possible intercultural interaction as well as unification into philosophical conceptual structure. In this sense reason is not exclusively given to Europeans, rather to all human beings of the world. In a similar development, Eze tells the importance of understanding a diversity of reason: "Diversity of conceptions of reason is thus something to be welcomed, not abolished" (Eze 2008: 100). The point is, therefore, an ethnocentric understanding of reason should be criticized to escape from an 
Binyam Mekonnen

ideology of reason in an intersubjective and intercultural philosophical perspective focusing on commensurable critical communication including all cultures and rationalities of the world. This focus on the voice of the 'Other' is the critical task of emancipative philosophy which opts for a communicative pluriversal dialogue. In Dussel's view plurivesal dialogue among world philosophical traditions is important in revealing and fostering a trans-modern critique. It is through a transmodern critique that another world is possible (Dussel 2008: 20). This critique is important in searching new perspectives from the underside of modernity and developing them in constructive conversation with the European modernity. This is a new way for the construction of global philosophy:

For a long time, perhaps for centuries, the many diverse philosophical traditions will each continue to follow their own paths, but nonetheless a global analogical project of a transmodern pluriverse (other than universal, and not post-modern) appears on the horizon. Now, "other philosophies" are possible because "another world is possible". (Ibid)

The rational to use a trans-modern pluriverse is to reconstruct a universal communication as it starts from the oppressed critique of the sacrificial myth of modernity. Since its project arises from the oppressed, then one may think that it is a postmodern outlook. But different from postmodernism, a trans-modern pluriverse works to maintain a universal rational communication between diverse philosophical traditions of the world. From this we can conclude that a transmodern universalism is constructed by the multitude philosophical cultures of the world and their possible interaction.

\section{Conclusion}

As part of contemporary critical theory, liberation philosophy and theology are given to question the fundamental anomic conditions of humanity within the project of modernity from the very interest of achieving human redemption. The theological aspect of liberation theory is important for its new interpretation of the Holy Bible underlying that the Gospel is primarily enlightening the 'poor', and religion has to be understood as a means of tackling any ideology which undermines and ignores human emancipation. I think this has a positive message to the religions of the world in the sense that believers need to use their faith not as opium, but rather an instrument of criticizing alienation of all kinds, and there the Creator is for nothing else beyond the goodness of subjects. This implies that the metaphysics of religion requires a concrete reflection so that the word of God is capable of enlightening the believers how to solve injustice. And this stand of 44 
liberation theology is applicable by employing a hermeneutic critique of the 'Other'/poor to the emancipative values and questions of religion and religious conventions.

The philosophic aspect of liberation discourse as it is discussed by Dussel is skeptical about the modernity treatment of the 'Other'. Most thinkers from the West describe the rational power of discourses in communicating the global population to discuss with the human liberation interest. For them today a rational communication can be held globally because there is an equal concern and voice in the world concerning the realization of emancipation. However, in Dussel's ethics of liberation we have seen the struggle of the 'Other' as it strives to accomplish human emancipation through the ethical understanding of the material. The material here signifies the development of the physical, spiritual and cultural condition of humans. Basically the dominant universal discourse of the West concedes the hegemonic imposition of an exclusive Eurocentric rationalism. In fact, currently thinkers like Habermas are claiming for the inclusion of the 'Other' just to explain human equality and dignity from their own cultural point of view. But this claim of Habermas is equivocal in the sense that he does not address how the asymmetric power relation of the world prohibits intersubjective communication among individuals and philosophical traditions of the world.

Despite this, Dussel says there is inequality in the present modern world, and the political will is therefore not the inclusion of the marginalized in the dominant culture of Eurocentrism, but the dialogical production of human universal values that arise from real philosophical critique and consensus. To start from the underside of modernity means not a passive and abstract inclusion of coloniality in modernity. Instead, it is to employ critical reflections from the rational force of the underside of modernity.

And finally, for me the liberation theory of Dussel provides a new and future oriented project that critically observes the emancipative-rational and irrationaldominating as well as excluding themes of modernity from its underside. As a philosophic quest the exteriority of modernity criticizes the irrational myth of estrangement. However, I do have two concerns on the accomplishment of this Dusselian project. The first one is to the extent to which the practicability of communication is maintained considering the particular language that people use to communicate universally if language is conventional and the promotion of a given cultural identity. And the second problem that I can see is the enlightenment possibility of the underside traditions. This is related with the dominant development of postmodernism in fostering particularism instead of universalism. The postmodern emphasis on the localization primacy is now a serious challenge to engage in a global communication. Indeed a trans-modern pluriverse aims at transcending postmodernism as it projects towards the worldhood communication. 


\section{Binyam Mekonnen}

But still the practices might not be easy as we are theorizing. And this is a practical danger for intercultural communication and its pluriversal alternative conversation. 
References

Best, Steven. 1995. The Politics of Historical Vision: Marx, Foucault, Habermas. New York and London: the Gullford Press.

Clarke, Simon. 2006. From Enlightenment to Risk: Social Theory and Contemporary Society. New York: Palgrave Macmillan.

Dussel, Enrique. 1993. Eurocentrism and Modernity (Introduction to the Frankfurt Lectures). Boundary 2, 20 (3): The Postmodern Debate in Latin America, 6576.

Dussel, Enrique. 1995. The Invention of the Americas: Eclipse of "the Other" and the Myth of Modernity. New York: Continuum.

Dussel, Enrique. 1996. The Underside of Modernity: Apel, Ricoeur, Rorty, Taylor, and the Philosophy of Liberation. Edited by Eduardo Mendieta. New Jersey: Humanities Press.

Dussel, Enrique. 1998. Ethics of Liberation in the Age of Globalization and Exclusion. Madrid: Trotta.

Dussel, Enrique. 2008. A New Age in the History of Philosophy: the World Dialogue Between Philosophical Tradition. Journal of Philosophy and Religion, 9(1), 1-22.

Eze, C. Emmanuel. (Eds.). 1997. Postcolonial African Philosophy: A Critical Reader. Cambridge: Blackwell Publishers Ltd.

Eze, C. Emmanuel. 2008. On Reason: Rationality in a World of Cultural Conflict and Racism. Durham and London: Duke University Press.

Foucault, Michel. 2007. The Politics of Truth. Cambridge, Massachusetts and London: MIT Press.

Habermas, Jurgen. 1987. The Philosophical Discourse of Modernity. Translated by Fredrick Lawrence. Massachusetts: MIT Press.

Habermas, Jurgen. 1987. The Theory of Communicative Action. Vol. 2 Life World and System: A Critique of Functionalism Reason. Translated by Thomas McCarthy. Boston: Beacon Press Books.

Habermas, Jurgen. 1992. Postmetaphysical Thinking. HohengartenM.William (trans.). Edited by Eduardo Mendieta. Cambridge: Polity Press.

Hanafi, Hassan. 2001. "Cultures, Conflict or Dialogue? Alternative Models," in Raul Forel-Betancourt, editor. Denktraitionen in DialogistudienZurBefreiung und Interkultralitat Band II. Frankfurt: Verlung Fur Interkulturelle Kummunikatim.

Hegel, G.W.F. 1975. Lectures on the Philosophy of World History: Introduction. Cambridge: Cambridge University Press.

Horkhiemer, Max and Theodor, W. Adorno. 1982. Dialectic of Enlightenment. Translated by Cumming John. New York: Continuum Publishing. 
Binyam Mekonnen

Kant, Immanuel. 1991. Political Writings. Cambridge: Cambridge University Press.

Kant, Immanuel. 1784. What is Enlightenment?

Levine, Andrew. 1993. The General Will: Rousseau, Marx, Communism. New York: Cambridge University Press.

Levine, Daniel H. 1998. "Assessing the Impacts of Liberation Theology in Latin America," the Review of Politics, 50 (2): 241-263.

Lowy, Michael. 1988. Marxism and Liberation Theology. Amsterdam: I.I.R.E.

Marx, Karl. 1975. Early Writings of Marx. London: Penguin Books Ltd.

Ramose, B. Magobe. 2002. African Philosophy through Ubuntu. Harare: Mond Books Publishers.

Rhodes, Ron. 2011. Christian Revolution in Latin America: the Changing Face of Liberation Theology: Part One in a Three-Part Series on Liberation Theology.

Retrieved from: http://www.home.earthlink.net/-ronrhodes/Liberation.html

Roelofs, H. Mark. 1988. "Liberation Theology: the Recovery of Biblical Radicalism." the American Political Science Review, 82(2): 549-566.

Sereqeberhan, Tsenay. 1997. "The Critique of Eurocentrism and the Practice of African Philosophy," Postcolonial African Philosophy: A Critical Reader. Edited by Emmanuel Chukwudi Eze. Cambridge: Blackwell Publishers Ltd.

Wimmer, M. Franz. 2002. Essays on Intercultural Philosophy. Chennai: Satya Nilayam Publications. 